\title{
PANDANGAN AL-QUR'AN TENTANG PEREMPUAN BEKERJA (HIKMAH DIBALIK SURAT AL-QASHASH)
}

\author{
Moh. Nurul Qomar \\ Institut Agama Islam Negeri Kudus, Indonesia \\ E-mail:mnqomar@iainkudus.ac.id
}

\begin{abstract}
The concept of gender is an even more interesting problem when it is associated with the perspective of Islam and the Koran. The role of women in the fabric of life is not in doubt. But there is still debate about permitting women to work outside the home among scholars. To better understand the concept of gender (women in the workplace) attached to Surat al-Qashash (28) verse 23, further analysis is needed using the content analysis approach in the commentary science corridor. Also, the library research approach is used to explore primary and secondary libraries to support this paper. Resulting in the conclusion that the Mufassir mentioned above does not differ significantly in interpreting Surah al-Qashash verse 23. However, the scholars differed in interpreting the father of two women who were assisted by Prophet Musa. b. Economic wisdom that can be learned from Surat al-Qashash verse 23 is that women are allowed to work as long as they can maintain their honor. Also, through this verse, it is understood that for economic activities (mu'amalah), a man is allowed to talk and see the opposite gender.
\end{abstract}

Keywords: Surat al-Qashash: 23; Working Women; Gender

Abstrak Konsep gender merupakan isu menarik lebih-lebih jika dikaitkan dengan perspektif islam dan al-Qur'an. Peran perempuan dalam tatanan kehidupan tidak diragukan lagi. Namun masih menjadi perdebatan tentang diperbolehkannya perempuan untuk bekerja di luar rumah di kalangan ulama'. Untuk lebih memahami konsep gender (wanita dalam bekerja) yang melekat pada surat al-Qashash (28) ayat 23 tentu diperlukan analisa lebih lanjut dengan menggunakan pendekatan analisis konten dalam koridor ilmu tafsir. Selain itu pendekatan library research digunakan untuk menelusuri pustaka baik primer maupun sekunder untuk mendukung tulisan ini. Sehingga menghasilkan simpulan bahwa: a. Para Mufassir yang disebut di atas tidak berbeda jauh dalam menafsirkan surat alQashash ayat 23. Akan tetapi para ulama' berbeda pendapat menafsirkan ayah dari dua perempuan yang ditolong oleh Nabi Musa. b. hikmah ekonomi yang dapat dipetik dari surat al-Qashash ayat 23 adalah diperbolehkan perempuan dalam bekerja, asalkan mampu menjaga kehormatannya, selain itu melalui ayat ini dapat dipahami bahwa atas kegiatan ekonomi (mu'amalah), seorang laki-laki diperbolehkan berbicara dan memandang lawan jenis.

Kata Kunci: Surat al Qashash: 23; Perempuan Bekerja; Gender

Permalink/DOI: https://doi.org/10.15408/harkat.v15i1.12972 


\section{Pendahuluan}

al-Qur'an sebagai pegangan hidup umat islam sekaligus sebagai sumber hukum islam sering kali menjadi bahan diskusi dan kajian yang tidak akan mati. Relevansi nash al-Qur'an dengan teori modern misalnya menjadi buah bibir pada forum-forum ilmiah. Salah satu isu yang hangat dan terus bergulir adalah kesetaraan gender. Konsep gender merupakan isu menarik lebih-lebih jika dikaitkan dengan perspektif islam dan al-Qur'an. Sering terjadi kesalahpahaman memahami konsep gender dalam perpektif islam dan al-Qur'an dengan menyimpulkan bahwa islam dan al-Qur'an menjadi hambatan dalam kesetaraan gender.

Islam sering menjadi tertuduh atas ketidak-adilan dalam hubungan laki-laki dan perempuan. Perbedaan gender mengakibatkan berbagai bentuk seperti marginalisasi atau pemiskinan ekonomi, stereotype bagi perempuan, kekerasan dan double burden (beban ganda) bagi perempuan (Suhra, 2013: 375).

Padahal islam memposisikan kaum perempuan sangat istimewa dalam al-Qur'an, terdapat surat secara khusus dengan sebutan surat an-Nisa' yang artinya surat perempuan. Disebut surat an Nisa' dikarenakan isi surat ini secara dominan memuat hukum dan aturan tentang perempuan yang tidak lagi dibahas pada surat lainnya. Selain surat an-Nisa' dalam alQur'an terdapat beberapa surat yang lain membahas tentang perempuan di antaranya: surat Mumtahanah, surat at-Thalaq, surat alAhzab dan surat al-Qashash, surat an-Nahl, surat al-Hujarat, surat al-Imran.
Pada surat al- Imran (3): 36 sebagaimana redaksinya disebutkan dalam al-Qur'an:

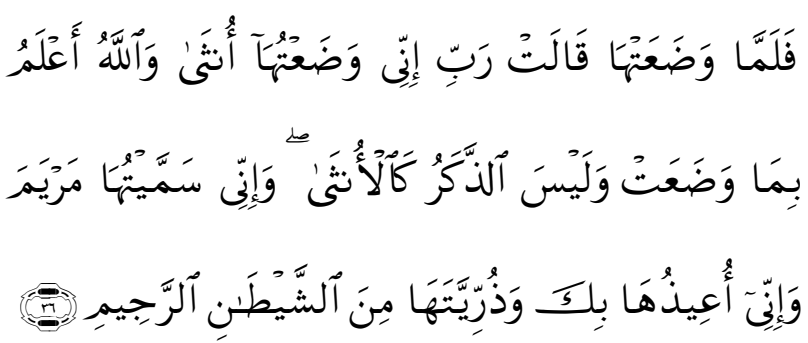

"Maka tatkala isteri 'Imran melahirkan anaknya, diapun berkata: "Ya Tuhanku, sesunguhnya aku melahirkannya seorang anak perempuan; dan Allah lebih mengetahui apa yang dilahirkannya itu; dan anak laki-laki tidaklah seperti anak perempuan. Sesungguhnya aku telah menamai Dia Maryam dan aku mohon perlindungan untuknya serta anak-anak keturunannya kepada (pemeliharaan) Engkau daripada syaitan yang terkutuk."

Ayat ini secara testual telah mendeskriminasikan kaum perempuan dan berlawanan dengan konsep gender. Akan tetapi bila dikaji berdasarkan ilmu tafsir al-Qur'an ayat tersebut menunjukkan persamaan derajat lakilaki dan perempuan dalam melakukan kegiatan sehari-hari terutama kegiatan yang berkaitan dengan amal sholeh (Halim K, 2014: 14-15).

Peran perempuan dalam tatanan kehidupan tidak diragukan lagi. Bagaimana alQur'an menceritakan Ratu Bulqis yang menjadi penguasa atas kerajaan Syaba'(Qs. An-Naml: 24-28). Maryam yang berani menentang hegemoni kaum laki-laki di Baitul Maqdis (Qs. Al- Imran). Bagaimana peran syaidatina Khadijah bin Walid dalam membantu Rosulallah dalam berdakwah. Namun masih menjadi perdebatan tentang diperbolehkannya perempuan untuk bekerja di luar rumah di kalangan ulama'.

Ulama yang melarang perempuan bekerja di luar rumah merujuk pada surat al-ahzab ayat 33 ; 


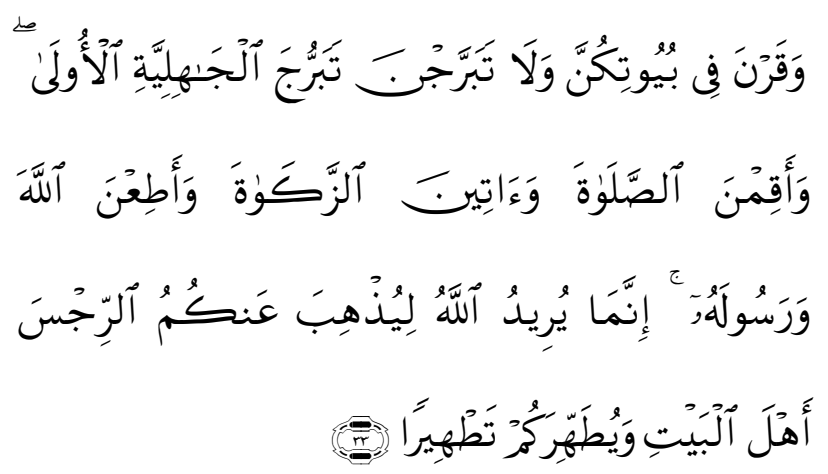

"dan hendaklah kamu tetap di rumahmu dan janganlah kamu berhias dan bertingkah laku seperti orang-orang Jahiliyah yang dahulu dan dirikanlah shalat, tunaikanlah zakat dan taatilah Allah dan Rasul-Nya. Sesungguhnya Allah bermaksud hendak menghilangkan dosa dari kamu, Hai ahlul bait dan membersihkan kamu sebersih-bersihnya"

Padahal di surat al-Qashash (28) ayat 23 diceritakan dua perempuan bekerja keras dalam memelihara binatang ternak di daerah madyan. Untuk lebih memahami konsep gender (wanita dalam bekerja) yang melekat pada surat alQashash (28) ayat 23 tentu diperlukan analisa lebih lanjut dengan menggunakan pendekatan analisis konten dalam koridor ilmu tafsir. Selain itu pendekatan library research digunakan untuk menelusuri pustaka baik primer maupun sekunder untuk mendukung tulisan ini.

Berdasarkan uraian di atas, dapat dikemukakan bahwa kajian utama pada artikel ini adalah bagaimana al-Qur'an berbicara tentang wanita bekerja sebagaimana tercantum pada surat al-Qashash (28) ayat 23?. Lebih lanjut kajian tersebut dikembangkan menjadi dua fokus. Pertama, bagaimana tafsir al-Qur'an surat al Qashash (28) ayat 23? Kedua, bagaimana hikmah ekonomi dari surat al-Qashash (28) ayat 23 ?

Belum terlalu banyak karya ilmiah yang membahas secara spesifik keterkaitan tafsir surat al-Qashash ayat 23 dengan kesetaraan gender (perempuan dalam bekerja), penelusuran kajian terdahulu dilakukan sebagai upaya untuk menemukan novelty.

Penelitian yang lainnya dari Solihatin (2017: 38-47) memberikan simpulan bahwa berdasarkan al-Qur'an perempuan dapat bekerja sama dengan suami untuk meningkatkan kesejahteraan keluarga, karena pada dasarnya perempuan mempunyai kesamaan peran dan kedudukan. Selain itu partisipasi perempuan dalam berbagai bidang kehidupan sebagai pekerja merupakan inisiatif perubahan budaya.

Selanjutnya Janah (2017: 167-185) menyebutkan bahwa al-Qur'an mengakui perbedaan antara laki-laki dan perempuan, akan tetapi perbedaan jenis kelamin tersebut tidak merugikan salah satu pihak apalagi menjadikan stereotype salah satunya.

Halim K (2014: 1-16) menyimpulkan bahwa secara tekstual membenarkan perbedaan jenis kelamin antara laki-laki dan perempuan namun perbedaan yang dimaksud bersifat biologis dan kodrat (perempuan mengandung, melahirkan dan menyusui sementara laki-laki tidak). Diluar itu potensi dan keunggulan lakilaki dan perempuan sama, baik hal yang positif maupun negatif.

Gender adalah istilah yang dipakai untuk menggambarkan perbedaan peran laki-laki dan perempuan, hasil dari olah pikir manusia sebagai akibat perkembangan sosial budaya masyarakat yang tidak bermakna kodrati. Terdapat dua pandangan yang berbeda dalam memahami konsep gender. Pertama, gender adalah bangunan social, sehingga laki-laki dan perempuan dalam tataran social tidak perlu adanya perbedaan peran dan perilaku gender dan bias gender harus dihilangkan. Kedua, berpendangan bahwa adanya perbedaan jenis kelamin laki-laki dan perempuan berakibat pada rangka konsep gender dalam kehidupan social, sehingga stereotip gender akan muncul pada peran dan fungsi tatanan social (Janah, 2017: 12). 
Menurut Suhra (2013: 377) Gender didefinisikan sebagai konsep yang dipakai untuk indentifikasi perbedaan laki-laki dan perempuan dalam perpektif social budaya. Lebih lanjut Suhra mengamini bahwa gender adalah suatu bentuk rekayasa masyarakat (social contructions), bukan perkara yang bersifat kondrati.

Teori yang familiar di tengah-tengah pengiat gender, salah satunya adalah teori feminis yang berusaha sekuat tenaga untuk menyuarakan suara perempuan yang selama ini merasa didiskriminasi dalam dominasi kaum laki-laki. Dalam hal ini Nasarudin mengkritik teori ini yang belum satu suara, mempunyai persepsi yang berbeda-beda tentang gender itu sendiri bahkan dengan semangat pembelaannya terhadap kaum perempuan terkesan utopis dan tidak realistis dengan kehidupan masyarakat (Janah, 2017: 175).

Meskipun begitu, diskusi tentang hak dan kewajiban perempuan agaknya tidak akan kunjung surut. Kehidupan perenpuan banyak menjadi obyek penelitian dan pengabdian kepada masyarakat, mulai dari fenomena maraknya tenaga kerja wanita (TKW) sampai dengan kebolehan seorang perempuan untuk bekerja.

Dalam masyarakat jahiliyah, perempuan menjadi objek penderita bahkan Umar bin Khattab mengubur hidup-hidup anak perempuannya sebelum beliau memeluk agama islam. Dengan hadirnya islam perempuan diberikan anugerah kemuliaan di dunia dan akhirat tanpa memandang perbedaan jenis kelamin, ras, dan suku. Hal ini selaras dengan firman Allah swt dalam Qs. Al-Isra':70.

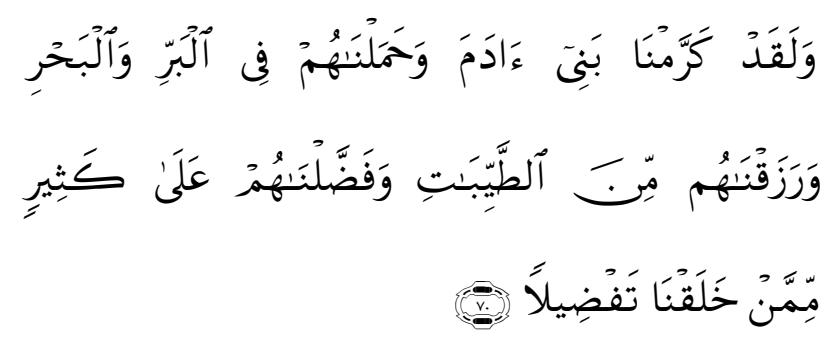

"dan Sesungguhnya telah Kami muliakan anakanak Adam, Kami angkut mereka di daratan dan di lautan, Kami beri mereka rezki dari yang baikbaik dan Kami lebihkan mereka dengan kelebihan yang sempurna atas kebanyakan makhluk yang telah Kami ciptakan.”

Ayat tersebut di atas menunjukkan bahwa al-Qur'an sangat mengutamakan kesetaraan gender antara laki-laki dan perempuan. Islam hadir dengan kesetaraan anugerah, hanya ketaqwaan dan amal sholeh yang menjadi pembeda. Artinya kesetaraan yang diakui oleh al-Qur'an bukan berarti harus sama peran dan tugas antara laki-laki dan perempuan dalam segala hal, namun harus ada keseimbangan peran dan fungsi, sehingga laki-laki dan perempuan sifatnya saling melengkapi.

Berbicara tentang bekerja dikaitkan dengan agama, Max Weber mempunyai pendapat bahwa rata-rata penganut protestan lebih giat bekerja dari pada penganut katolik. Weber mesangsikan keterbelakangan penganut katolik dalam hal ekonomi lebih disebabkan karena gereja mengajarkan supaya orang tidak terlalu focus pada duniawi dan suka rela menanti datangnya kebahagiaan surga. Karena "pengasingan" dari duniawi tidak menutup kemungkinan dari tujuan dagang dan penumpukkan kapital (Weber, 2007:4).

Bekerja merupakan sarana utama untuk menjamin datangnya rejeki dan menjaga stabilitas kehidupan masyarakat, sehingga bekerja mampu dinilai ibadah dihadapan Allah swt jika dilakukan sesuai dengan tuntunan ajaran islam. Berkaitan dengan perempuan dalam bekerja, melihat masa awal islam, maka dapat 
dikatankan bahwa islam membenarkan perempuan melakukan berbagai aktivitas, termasuk diperbolehkan perempuan dalam bekerja dalam berbagai bidang, baik di dalam rumah maupun di luar rumah

\section{Pembahasan}

\section{Profil Surat Al-Qashash}

Al-Qur'an terdiri dari 30 juz dan 114 surat, salah satunya adalah surat al-qashash. Disebut surat al-qashash yang berarti cerita atau kisah dikarenakan pada ayat 25 terdapat kata Qashash. Kata Qashash dan seakar dengannya dalam al-Qur'an terulang 26 kali yang tersebar pada 12 surat dan 21 ayat, sehingga kisah atau cerita merupakan bagian yang tidak teripisahkan dengan al-Qur'an yang berfungsi untuk mengemukakan bantahan terhadap kepercayaankepercayaan yang salah.

Surat ini tergolong surat-surat makkiyah dan terdiri dari atas 88 ayat. Artinya surat ini diturunkan ketika kaum muslimin berada di kota mekkah dan masih sedikit jumlahnya dan dalam kondisi lemah, sementara kaum kafir quraisy berada dalam kondisi kuat dan berkuasa.

Surat ini turun untuk menjelaskan ukuran-ukuran yang sebenarnya tentang kekuatan dan nilai. ada standar kekuatan dan nilai yang berbeda yang bersumber dari Allah swt yang disebut nilai keimanan. Barang siapa yang memegang nilai keimanan tersebut, maka kebaikan ada pada dirinya. sebaliknya barang siapa tidak memilikinya dan bahkan menjadi musuh dari nilai keimanan tersebut, maka dirinya tidak akan damai dan tidak tertolong.

Isi dari Surat al-Qashash memiliki keterkaitan dengan surat sebelumnya yaitu surat an-Naml. Terdapat persamaan antara keduanya saling berhubungan. Adapun beberapa persamaan antara keduanya sebagai berikut (jabar.kemenag.go.id): Pertama, kedua surat ini di awali dengan huruf-huruf terputus atau dikenal dengan istilah al-Huruf al-Muqatha'ah yaitu, طسن dan dedua, beberapa kisah nabi yang terdapat pada surat an-Naml dilanjutkan pada surat al-Qashash. Ketiga, pada akhir surat an-Naml ayat 92 terdapat perintah kepada Nabi Muhammad sebagaimana tertulis sebagai berikut:

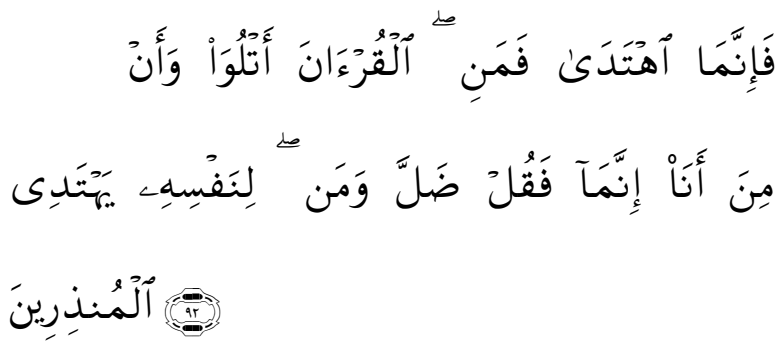

"Dan supaya aku membacakan Al Quran (kepada manusia). Maka Barangsiapa yang mendapat petunjuk Maka Sesungguhnya ia hanyalah mendapat petunjuk untuk (kebaikan) dirinya, dan Barangsiapa yang sesat Maka Katakanlah: (Sesungguhnya aku (ini) tidak lain hanyalah salah seorang pemberi peringatan)".

Sedangkan pada surat al-Qashash ayat ketiga terdapat kata kerja yang sama dengan surat an-Naml dan secara spesifik menegaskan kebenaran kisah Nabi Musa dan Fir'aun dengan kemasan teks sebagai berikut:
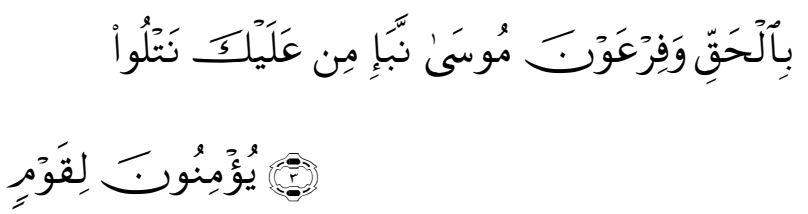

"Kami membacakan kepadamu sebagian dari kisah Musa dan Fir'aun dengan benar untuk orang-orang yang beriman”

Isi surat al-Qashash didominasi kisah Nabi Musa dan Fir'aun yang menggambarkan kekuasaan yang tidak dilandasi keimanan kepada Allah swt terdapat di awal-awal surat dan diakhir surat ditutup kisah Qorun dengan kesombongan harta dan ilmu pengetahuannya. 
Fir'aun yang memiliki tentara perang yang rela mati di medan perang menjadi ketakutan dengan bayi laki-laki dari golongan yahudi sehingga seluruh bayi laki-laki di seluruh mesir dibunuh. Dengan kuasa Allah swt, Musa kecil hadir ditengah keluarga Fir'aun dan menjadi buah hati istri Fir'aun. Musuh yang dicari diluar untuk dibunuh, karena diramalkan akan mengganggu kekuasaan Fir'aun dikemudian hari menjadi bagian dari istana dan dibesarkan dipangkuan Fir'aun. Ketika Musa diperintahkan oleh Allah swt berdakwak kepada Fir'aun. Ia tetap mempertahankan kesombongan kekuasaannya dan bahkan mengaku sebagai tuhannya rakyat Mesir. Kekuasaan tanpa adanya ridho dari Allah swt maka kekuasaan tersebut tanpa arti dan menjadi kemudharatan bagi dirinya dan masyarakat sekitar. Sedangkan Qorun yang membanggakan harta dan ilmu pengetahuannya menjadi ibrah yang sama dengan kisah Fir'aun di mana Qorun yang memiliki harta yang melimpah menjadi sombong dan lupa akan kuasa Allah pada dirinya.

Kedua kisah tersebut terdapat kesamaan, antara lain: Pertama, baik Fir'aun dan Qorun menolak dan meniadakan hadirnya Allah swt pada kesuksesannya. Kedua, Allah swt secara langsung bertindak dengan menghancurkan kekuasaan Fir'aun dan menghilangkan harta dan ilmu pengetahuan Qorun. Ketiga, kematian Fir'aun bukanlah di medan perang dan Qorun tidak dibunuh saat dihadang perampok, akan tetapi keduanya meninggal atas kuasa Allah swt, satunya mati di laut lapas karena mengejar Nabi Musa dan Qorun meninggal ditelan bumi bersama harta kekayaannya.

\section{Overview Surat al-Qashash Ayat 23}

Tulisan ini secara khusus mengkaji surat al-Qashash ayat 23 sebagai berikut:

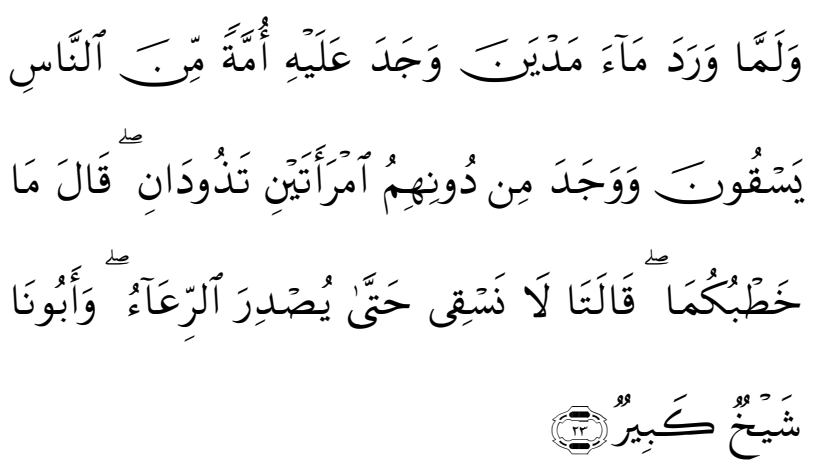

"Dan tatkala ia sampai di sumber air negeri Mad-yan ia menjumpai di sana sekumpulan orang yang sedang meminumkan (ternaknya), dan ia men- jumpai di belakang orang banyak itu, dua orang wanita yang sedang menghambat (ternaknya). Musa berkata: "Apakah maksudmu (dengan berbuat begitu)?" kedua wanita itu menjawab: "Kami tidak dapat meminumkan (ternak kami), sebelum pengembala-pengembala itu memulangkan (ternaknya), sedang bapak Kami adalah orang tua yang telah lanjut umurnya".

Surat al-Qashash ayat $23 \mathrm{di}$ atas mempunyai keterkaitan dengan ayat sebelumnya surat al-Qashash ayat 22, di mana Nabi Musa berangkat ke kota Madyan, sebelum berangkat beliau berdoa "Mudah-mudahan Tuhanku memimpinku ke jalan yang benar". Sehingga kemudian bertemu dengan sekelompok pengembala domba yang mengerumuni sumur dan dua perempuan.

Menariknya adalah kota Madyan (terletak dekat pantai Laut Merah, di perbatasan Yordania dan Palestina) menjadi tujuan Nabi Musa ternyata disebut dan menjadi setting lokasi di beberapa ayat dalam al-Qur'an, di antaranya pada Surah At Taubah: 70: 


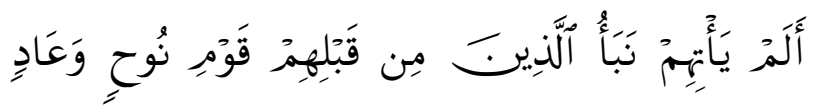

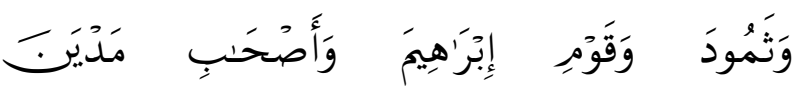

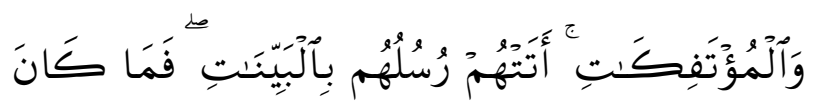

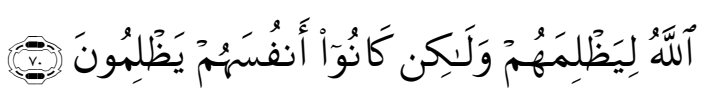

"Belumkah datang kepada mereka berita penting tentang orang-orang yang sebelum mereka, (yaitu) kaum Nuh, 'Aad, Tsamud, kaum Ibrahim, penduduk Madyan dan negeri-negeri yang telah musnah?. telah datang kepada mereka Rasul-rasul dengan membawa keterangan yang nyata, Maka Allah tidaklah sekali-kali Menganiaya mereka, akan tetapi merekalah yang Menganiaya diri mereka sendiri”.

Pada surat Al Hijr ayat 78,

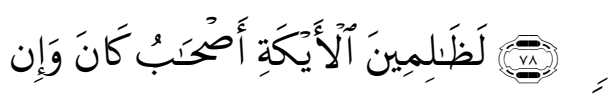

“dan Sesungguhnya adalah penduduk Aikah itu benar-benar kaum yang zalim.”

Pada surat Thaha ayat 40,
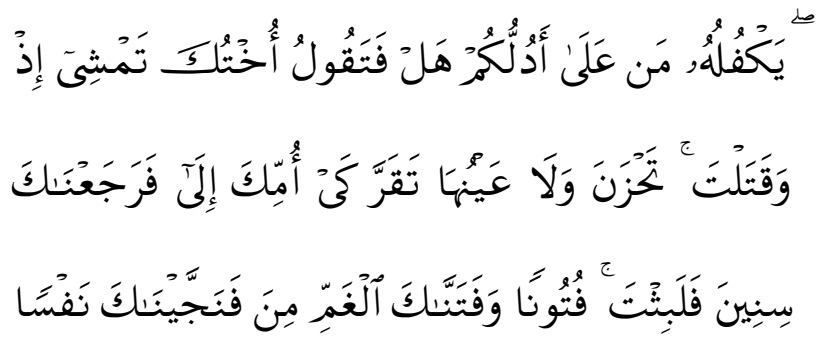

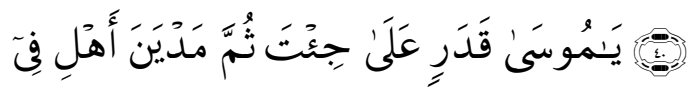

"(yaitu) ketika saudaramu yang perempuan berjalan, lalu ia berkata kepada (keluarga Fir'aun): "Bolehkah saya menunjukkan kepadamu orang yang akan memeliharanya?" Maka Kami mengembalikanmu kepada ibumu, agar senang hatinya dan tidak berduka cita. dan kamu pernah membunuh seorang manusia, lalu Kami selamatkan kamu dari kesusahan dan
Kami telah mencobamu dengan beberapa cobaan; Maka kamu tinggal beberapa tahun diantara penduduk Madyan, kemudian kamu datang menurut waktu yang ditetapkan, Hai Musa,"

Pada surat al-Hajj ayat 44:

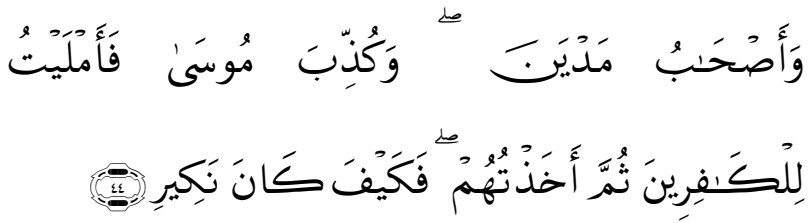

"Dan penduduk Madyan, dan telah didustakan Musa, lalu aku tangguhkan (azab-Ku) untuk orang-orang kafir, kemudian aku azab mereka, Maka (lihatlah) bagaimana besarnya kebencian$\mathrm{Ku}$ (kepada mereka itu)”

Beberapa surat memiliki hubungan langsung dengan surat al-Qashash yang sama mengkisahkan nabi Musa dan Fir'aun (surat alHajj ayat 44, surat Thaha ayat 40). Surat yang lain tidak ada hubungan dengan surat alQashash selain persamaan setting lokasi Kota Madyan.

Pada surat al-Hijr ayat 78 tidak secara langsung menyebut Madyan, namun banyak pendapat bahwa penduduk Aikah yang dimaksud adalah kawasan hutan terletak di kota Madyan dan diketahu secara umum tempat tinggal Nabi Syu'aib adalah Kota Madyan.

Ada pendapat yang mengemukakan bahwa Nabi Syu'aib adalah menantunya Nabi Musa, namun pada surat al-Qashash ayat 23 tidak menyebutkan secara gambling nama ayah dari ayah dari 2 perempuan pengembala domba tersebut. Pada ayat tersebut hanya menyebutkan syaikhun kabir.

\section{Tafsir Surat al-Qashash Ayat 23}

Selanjutnya akan dipaparkan tafsir surat al-Qashash Ayat 23 dari beberapa ulama', antara lain: Qutub (2009) dalam menafsirkan ayat ini, 
beliau memberikan komentar pada bagian sekelompok laki-laki pengembala domba yang tidak memberikan kesempatan kepada dua perempuan sesame pengembala terlebih dahulu untuk memberikan minuman kepada dombanya. Seharusnya laki-laki yang mempunyai muru'ah dan fitrah harus memberikan kesempatan terlebih dahulu kepada seorang perempuan. Dalam hal ini Musa mempunyai sifat keduanya sehingga meskipun dirinya lelah setelah perjalanan jauh dan mungkin juga dalam keadaan lapar dan dahaga, namun beliau berusaha membantu memberikan minuman domba-domba dua perempuan tersebut.

Sedangkan menurut al-Maraghi (1974), ayat ini menjelaskan fenomena aneh menurut Musa, di mana sekelompok pengembala laki-laki tidak memperdulikan teman perempuan seprofesi dalam hal memberikan air minum untuk dombanya. Sehingga Musa mendatangi kedua perempuan tersebut dan bertanya hal tersebut, keduanya pun memberitahukan factor yang menyebabkan dirinya dalam kondisi demikian. Sebabnya mereka lemah dan tidak mampu berebut air dengan kaum laki-laki. Mendengar alas an tersebut, Musa segera bergerak untuk menyelesaikan masalah yang dihadapi dua perempuan tersebut.

Shihab dalam tafsir misbah menjelaskan ayat ini sebagai berikut; Sesampainya Musa di kota madyan dan mendapati sumber air yang dikelilingi sekumpulan orang yang sedang meminumkan ternak mereka dan mendapati dibelakang mereka dua orang perempuan yang sedang menambatkan ternaknya. Melihat keadaan tersebut Musa merasa iba dan merasa heran melihat fenomena tersebut, kemudia dia bertanya "apakah maksud berdua berda di sini sambil menghabat ternak kamu minum sebagaimana ternak-ternak minum? Sesuai dugaan Musa jawaban dua perempuan tersebut mengisyaratkan bantuan " kami tidak dapat meminumkan ternak kami sebelum pengembala- pengembala itu pulang meninggalkan tempat air. Kami perempuan yang lemah, tidak memiliki saudara laki-laki dan ayah kami sudah tuah tidak mampu lagi berdesak-desakan dengan mereka”. Mendengar jawaban tersebut Musa segera bergegas meskipun dalam kondisi haus dan lapar mengambilkan air untuk kedua perempuan tersebut dan kembali lagi untuk memberikan air untuk ternak.

Beberapa pendapat sebagaimana terurai di atas, tidak beda jauh dan saling mempertegas alur dari ayat tersebut. Misalnya Qutub memetingkan sifat muru'ah pada seorang lakilaki, al Maghrawi mempertegas alasan dua perempuan pengembala yang teringgal untuk memberika air pada dombanya, yaitu mereka seorang yang lemah dan tidak mampu berebut dengan kaum laki-laki.

Namun pada kata syaikhun kabir, para mufassir berbeda pendapat. Menurut sebagian dimaknakan Nabi syu'aib dengan menyakan kota tempat tinggal, meskipun tidak ada keterangan secara tegas.

\section{Hikmah Surat al-Qashash Ayat 23 dalam Sudut Pandang Ekonomi}

Mengacu pada penafsirat surat al-Qashash ayat 23 tersebut di atas dapat diambil beberapa hikmah yang mampu dijadikan pedoman dalam kehidupan sehari-hari adapun hikmah tersebut antara lain: Pertama, diperbolehkannya perempuan untuk bekerja diluar rumah. Hikmah ini diambilkan dari:

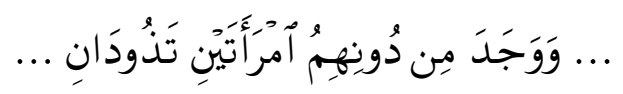

“...ia men- jumpai di belakang orang banyak itu, dua orang wanita yang sedang menghambat (ternaknya)...."

Ayat tersebut menggambarkan dua perempuan sebagai pengembala domba sedang menunggu giliran untuk memberi minum 
ternaknya. Dua perempuan tersebut dari keluarga beriman kepada Allah swt terbukti salah satu dari keduanya akan dinikahkan dengan Nabi Musa. Sebagaimana ayat selanjutnya pada surat al-Qashsash ayat 27:

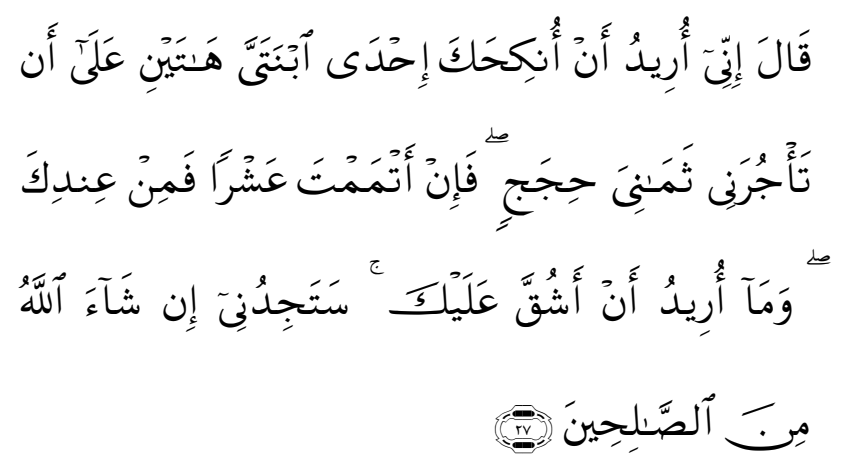

"Berkatalah Dia: "Sesungguhnya aku bermaksud menikahkan kamu dengan salah seorang dari kedua anakku ini, atas dasar bahwa kamu bekerja denganku delapan tahun dan jika kamu cukupkan sepuluh tahun Maka itu adalah (suatu kebaikan) dari kamu, Maka aku tidak hendak memberati kamu. dan kamu insya Allah akan mendapatiku Termasuk orang- orang yang baik".

Artinya perempuan bekerja tidaklah melanggar aturan agama, lebih-lebih lagi ketika mengamini bahwa ayah dari dua perempuan tersebut adalah Nabu Syu'aib, di mana syariat nabi sebelum Nabi Muhammad akan menjadi syariat islam juga selama tidak ada keterangan yang membatalkan syariat tersebut (Shihab, 2005: 331). Lebih lanjut Beliau menjelaskan bahwa pada prinsipnya islam memperbolehkan perempuan untuk bekerja baik di dalam rumah maupun di luar rumah (Shihab, 2005:332).

Dalam hal ini Qomar (2014: 76) memberi simpulan makna kerja dalam islam sebagai bagian bentuk perintah Allah swt yang harus dikerjakan dengan penuh rasa syukur atas nikmat sehat dan iman yang diberikan oleh Nya. Maknanya laki-laki maupun perempuan berhak bersempatan untuk bekerja sebagai perwujudan rasa taqwanya kepada Allah swt.
Kedua, melalui potongan ayat yang sama, dapat diambil hikmah bahwa diperbolehkan perempuan dalam bekerja dengan syarat perempuan tersebut mampu menjaga etika dan kehormatan seorang muslimah.

Perempuan yang bekerja di luar rumah tidak diperbolehkan bersoleh secara berlebihan dan bersikap genit terhadap teman laki-laki di tempat kerja. Solihatin (2017: 42) memberikan catatan etika perempuan dalam bekerja yang harus ditaati sebagaimana tersebar di beberapa surat al-Qur'an. a. menjaga sopan santun (alA'raf: 199). b. berakhlak mulia (al-Isra': 37). c. menjaga kehormatan diri (an-Nisa': 25). d. bekerja berdasakan profesionalisme (al-Isra: 84). e. pekerjaan yang ia lakukan sesuai kodrat (alIsra: 84$)$. f. tetap menjaga tujuan keluarga yaitu sakinah (ar-Rum: 21). g. tetap menjaga musyawarah antara suami dan istri (al-Imran: 159).

Ketiga, diperbolehkan perempuan bergaul dengan kaum laki-laki dengan tujuan bermu'amalah. Hikmah ini diambil dari:

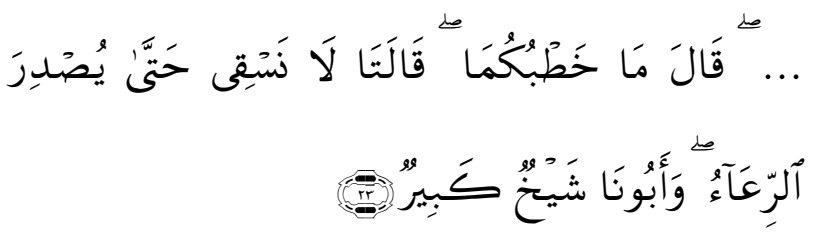

“...Musa berkata: "Apakah maksudmu (dengan berbuat at begitu)?" kedua wanita itu menjawab: "Kami tidak dapat meminumkan (ternak kami), sebelum pengembala-pengembala itu memulangkan (ternaknya), sedang bapak Kami adalah orang tua yang telah lanjut umurnya".

Ayat tersebut diatas menggambarkan percakapan antara Musa dan dua perempuan. Musa yang mempunyai rasa khusu' kepada Allah swt tetap memberanikan diri untuk bertanya kepada dua perempuan tersebut. Artinya dalam fiqh diperbolehkan laki-laki berbicara dengan perempuan non muhrim atas dasar mu'amalah, perlu digarisbahwai disini kegiatan berbicara dengan lawan jenis tidak boleh berlebihan. 


\section{Penutup}

Berdasarkan uraian di atas, penulis menyimpulkan bahwa: a. Para Mufassir yang disebut di atas tidak berbeda jauh dalam menafsirkan surat al-Qashash ayat 23. Akan tetapi para ulama' berbeda pendapat menafsirkan ayah dari dua perempuan yang ditolong oleh Nabi Musa. b. hikmah ekonomi yang dapat dipetik dari surat al-Qashash ayat 23 adalah diperbolehkan perempuan dalam bekerja, asalkan mampu menjaga kehormatannya, selain itu melalui ayat ini dapat dipahami bahwa atas kegiatan ekonomi (mu'amalah), seorang laki-laki diperbolehkan berbicara dan memandang lawan jenis.

\section{Daftar Pustaka}

Halim K, Abd. Konsep Gender dalam AlQur'an: Kajian Tafsir Tentang Gender dalam Qs. Ali Imran (3): 36, Jurnal alMaiyyah, Vol. 7 No. 1 Januari-Juni 2014.

Janah, Nasitotul. Telaah Buku Argumentasi Kesetaraan Gender Perspektif al-Qur'an Karya Nasaruddin Umar, Jurnal Sawwa, Vol. 12 No. 2 April 2017.

Maraghi, Ahmad Musthafa. Tafsir Maraghi. Diterjemahkan. Semarang: CV. Thoha Putra, 1974.

Qomar, M. Nurul. Makna Kerja Perspektif Ekonomi Syari'ah, Jurnal Irtifaq, Vol. 1 No. 22014.

Qutub, Sayyid., Tafsîr Fî̀ zilâl Al- Qur'an: Dibawah Naungan Al- Qur'an. Jakarta: Rabbani Press, 2009.

Shihab, M Quraish. Tafsir Al- Misbah: Pesan, Kesan, dan Keserasian Al- Qur'an. Jakarta: Lentera Hati, 2005.

Solihatin, Isna Rahmah. Konsepsi Al-Qur'an Tentang Perempuan Pekerja Dalam Mensejahterakan Keluarga: Kesetaraan dan Kebijakan, Harkat; Media Komunikasi Islam Tentang Gender dan Anak, Vol. 12 No 22017.

Suhra, Sarifa. Kesetaraan Gender dalam Perpektif al-Qur'an dan Implikasinya Terhadap Hukum Islam, Jurnal al-Ulum, Vol. 13 No.2 Desember 2013.

Weber, Max. Etika Protestan dan Semangat Kapitalisme.Yogyakarta: Jejak, 2007.

http: //www.jabar. kemenag.go.id/ opini-59 Mengenal Surah al Qashash 